IRA-International Journal of Management \& Social Sciences

ISSN 2455-2267; Vol.05, Issue 01 (2016)

Pg. no. 66-70

Institute of Research Advances

http://research-advances.org/index.php/RAJMSS

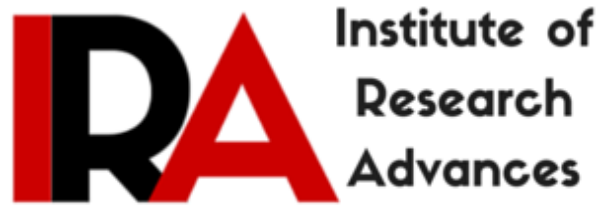

\title{
Socio-economic status of fishermen in district Srinagar of Jammu and Kashmir
}

\author{
${ }^{1}$ Nasir Husain, ${ }^{2}$ M.H. Balkhi, ${ }^{3}$ T.H. Bhat and ${ }^{4}$ Shabir A. Dar \\ ${ }^{\mathbf{1 , 2 , 3 , 4}}$ Faculty of Fisheries, Sher-e-Kashmir University of Agricultural Sciences \& \\ Technology of Kashmir, Rangil, Ganderbal - 190 006, J\&K, India.
}

Type of Review: Peer Reviewed.

DOI: http://dx.doi.org/10.21013/jmss.v5.n1.p8

\section{How to cite this paper:}

Husain, N., Balkhi, M., Bhat, T., \& Dar, S. (2016). Socio-economic status of fishermen in district Srinagar of Jammu and Kashmir. IRA-International Journal of Management \& Social Sciences (ISSN 2455-2267), 5(1), 66-70. doi:http://dx.doi.org/10.21013/jmss.v5.n1.p8

(C) Institute of Research Advances

\section{(c) ) EY-NG}

This work is licensed under a Creative Commons Attribution-Non Commercial 4.0 International License subject to proper citation to the publication source of the work.

Disclaimer: The scholarly papers as reviewed and published by the Institute of Research Advances (IRA) are the views and opinions of their respective authors and are not the views or opinions of the IRA. The IRA disclaims of any harm or loss caused due to the published content to any party. 


\begin{abstract}
A Socio-economic status of fishermen living on the banks of River Jhelum, Dal Lake and Anchar Lake was investigated in district Srinagar of Jammu and Kashmir. The total numbers of 150 samples of respondent were selected randomly from the areas and the information was collected by in-depth guided interviews through well structured pre-tested schedule developed for the study. The result of the study revealed that the age group of the fishermen varied between 20 to 60 years. About $57 \%$ of total respondent were found to belong under the age group between 41-50 years. Illiteracy was found one of the major problems of the study area about $49 \%$ respondents was found to be illiterate. Economic conditions of the fishermen revealed that the $42 \%$ of fishermen income of Rs. $5001-R s .10000$ per month. If fishery facilities of these areas are improved upon, it could support the strides towards employment generation and poverty alleviation.
\end{abstract}

Key words: Fishermen, literacy, socio-economic.

\title{
INTRODUCTION
}

Fish and fishing business is an important sector of many nations of the world from the standpoint of income and employment generation. Fishing plays an important role in supporting livelihood worldwide and also forms an important source of diet for over one billion people. In India fisheries sector occupies a very important place in the socio-economic development. It serves as a form of income, provides employment to about 14 million people and impulse growth of a number of subsidiary industries and is a source of cheap and nutritious food. Fishing is generally considered a low profession in India and practiced mainly by the members of backward communities who are largely illiterate, superstitious and extremely poor. The main factor that has influenced this profession is the socio-economic condition of the fishermen community. For the proper development of the fishing industry and fishermen, there socio-economic advancement is necessary.

The total fishermen population in the Jammu and Kashmir State as per livestock census 2003 was around 31,000 . It is presently estimated at 81728 . The $27781 \mathrm{Km}$. length of rivers/streams facilitates farming of more than 40 million tonnes of fish. As against this, the State has only 0.07 lakh hectares under reservoir area. There is a big gap between the demand and supply of fish. Fish is a valuable element of diet of the local people throughout the year. There are 1248 lakes including water bodies and water is spread into 39921.8 hectares of area which gives an indication of the potential for fisheries in the State. The main aspect was taken into consideration for the present study with the aims to study the socio-economic status of fishermen in the study area.

\section{MATERIAL AND METHODS}

For the present study, Srinagar District of Jammu and Kashmir was selected purposively, as this was considered to be representative of the socio-economic conditions of the region and moreover, district has considerable number of fishermen population. From Srinagar district, the socioeconomic investigation was carried out of fishermen living on the banks of River Jhelum, Dal Lake and Anchar Lake. A total number of 150 fishermen were selected randomly for the study. The socio-economic information was collected through personal interview method on a well structured pre- tested schedule developed for the purpose. The secondary data was collected from newspapers, fisheries bulletins of Jammu and Kashmir, journals and published books. Moreover, personal knowledge was used to make meaningful interpretation of the data.

\section{RESULTS AND DISCUSSION} below.

The analyses on the studies conducted on the socio - economic status of fishermen are given 


\section{Age distribution of the respondents}

The age distribution of respondent is presented in Table 1 . The table reveals that the age group of the fishermen varied between 20 to 60 years. Table further reveals that the most of the fishermen belonged to the age group of 41-50 years (56.67\%) followed by age group 31-40 years (24.67\%), age group 51-60 years (13.33\%) and it was lowest 5.33 per cent for the age group 21-30 years.

Table 1: Age Distribution of respondents

\begin{tabular}{|c|c|c|}
\hline Age Group (Year) & No. of respondents & Percentage \\
\hline $21-30$ & 8 & 5.33 \\
\hline $31-40$ & 37 & 24.67 \\
\hline $41-50$ & 85 & 56.67 \\
\hline $51-60$ & 20 & 13.33 \\
\hline Total & 150 & 100 \\
\hline
\end{tabular}

\section{Educational level of the respondents}

The Educational level of respondent is presented in Table 2. The table reveals that the fishermen of the study area are still educationally backward. Table further reveals that the maximum numbers of respondents were illiterate about 49 per cent followed by the ones who are having qualification up to primary level 20.67 per cent, middle level 15.33 per cent, high school 10.67 per cent and it was lowest secondary level 4.00 per cent. The reason for the less literacy rate was found to be the poverty.

\section{Family size of the respondents}

The Family size of the respondents is presented in Table 3. The table reveals that that most of the fishermen having a family size of 3-4 members in their family (43\%) followed by family size 5-6 members (36\%), 7-8 members (15.33\%) and 9-10 members (5.33\%).

Table 2: Educational level of the respondents

\begin{tabular}{|l|c|c|}
\hline Dimension & Number of respondents & Percentage \\
\hline Illiterate & 74 & 49.33 \\
\hline Primary level & 31 & 20.67 \\
\hline Middle level & 23 & 15.33 \\
\hline High school level & 16 & 10.67 \\
\hline Secondary level & 6 & 4.00 \\
\hline Total & 150 & 100 \\
\hline
\end{tabular}




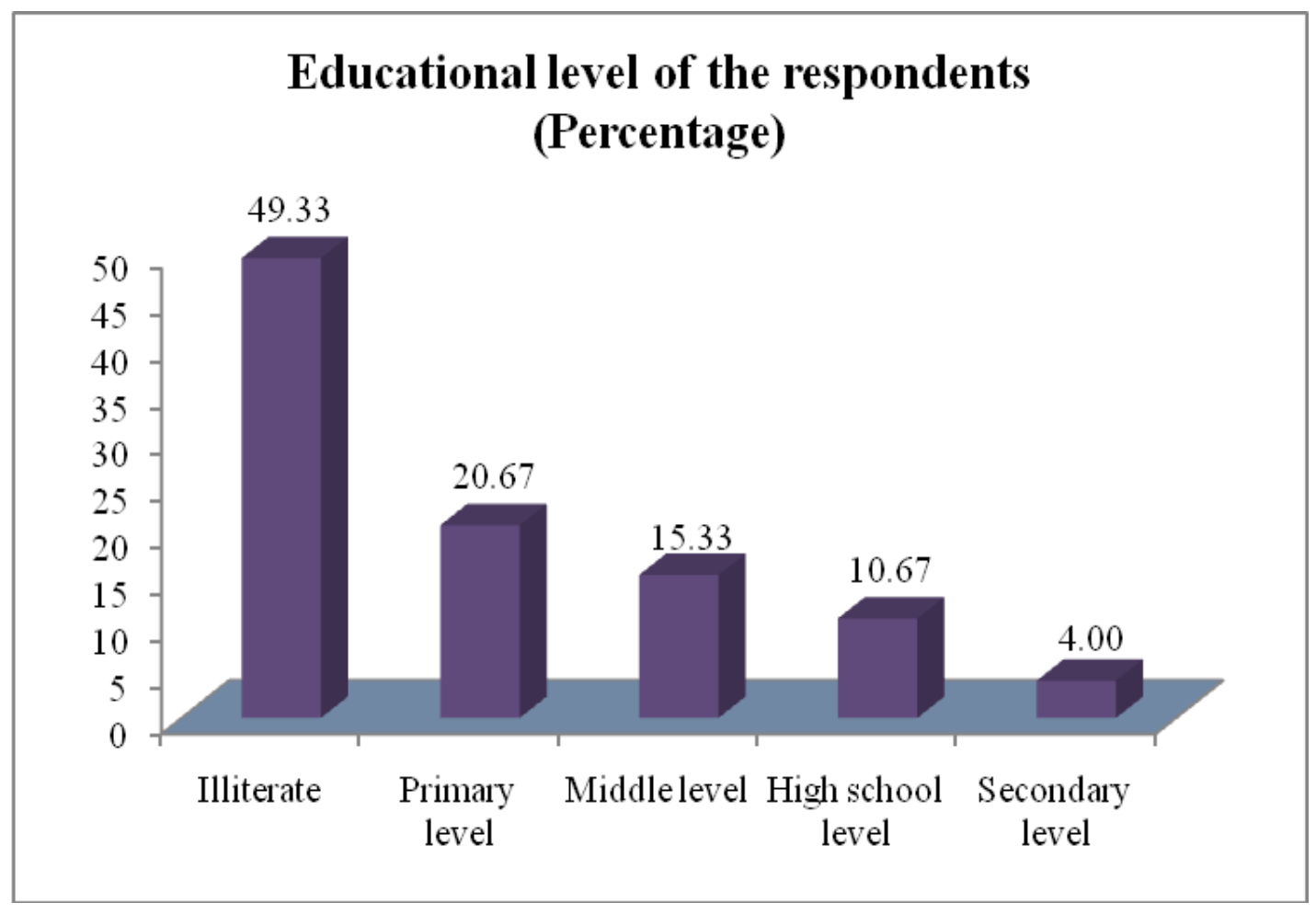

Table 3: Family size of the respondents

\begin{tabular}{|c|c|c|}
\hline $\begin{array}{l}\text { Dimension } \\
\text { (Nos.) }\end{array}$ & Number of respondents & Percentage \\
\hline $3-4$ & 65 & 43.33 \\
\hline $5-6$ & 54 & 36.00 \\
\hline $7-8$ & 23 & 15.33 \\
\hline $9-10$ & 8 & 5.33 \\
\hline Total & 150 & 100 \\
\hline
\end{tabular}

\section{Income distribution of the respondents}

The income distribution of the respondents is presented in Table 4. Income is the decisive factor mostly used for determining the living standard of the any community or region. Equitable distribution of the income further enhances the social harmony among different section of our population.

Table 4: Income distribution of the respondents

\begin{tabular}{|l|c|c|}
\hline $\begin{array}{c}\text { Income level } \\
\text { Rs/Month) }\end{array}$ & No. of respondents & Percentage \\
\hline$<5000$ & 11 & 7.33 \\
\hline $5001-10000$ & 63 & 42.00 \\
\hline $10001-15000$ & 41 & 27.33 \\
\hline $15001-20000$ & 28 & 18.67 \\
\hline$>20000$ & 7 & 4.67 \\
\hline
\end{tabular}




\section{Income distribution of the respondents}

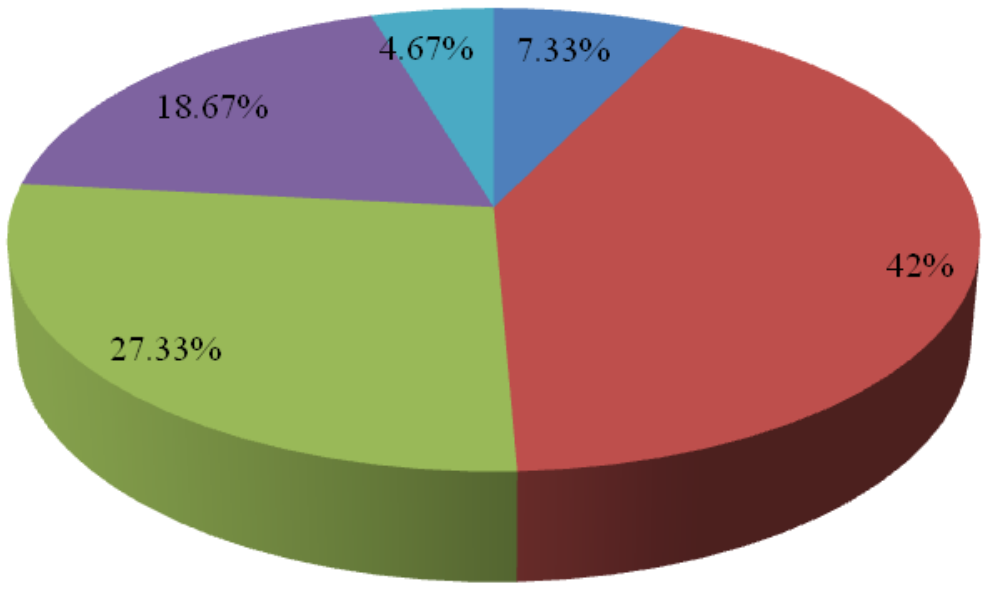

Income level

- $<5000$

— 5001-10000

- 10001-15000

- 15001-20000

$\square>20000$

The table reveals that the income level of fishermen of the study area was varied from Rs. 5000 to Rs. 20000 per month. It was observed that the 42 per cent of the fishermen income level was Rs. 5001- Rs. 10000 followed by income level of Rs. 10001 - Rs. 15000 (27.33 \%), Rs.15001 - Rs.20000 (18.67\%), less than Rs.5000 (7.33\%) and only 4.67 per cent monthly income of the fishermen was more than Rs.20000.

\section{REFERENCES}

Bhaumik , Utpal., Mittal, I.C., Das, P., and Paria, T., 2005. Some Socio-economic aspects of the fishermen of twin pronged floodplain wetlands in West Bengal. J. Indian Fish. Assoc., 32: 119-133.

Bhaumik, Utpal and Pandit, P.K., 1991. Socio-economic status of fishermen in some beels of West Bengal. Environ. \& Ecol., 9(3):600-603.

Das, S.K., Rao, P.K. and Raj, R.K., 2004 \&2005. Socio-Economic Status of Goat Farmers in Orissa. Journal of Extension Education. Vol.IX\&X, No. 1\&2: 51-55.

Economic Survey J\&K2013-14: Directorate of Economic and Statistics, Jammu and Kashmir.

Handbook on Fisheries Statistics 2014. Department of Animal Husbandry, Dairying and Fisheries, Ministry of Agriculture, Government of India New Delhi.

Kalita, G. J., Sarma, P. K., Goswami, P., and Rout, S., 2015. Socio-economic status of fishermen and different fishing gear used in Beki River, Barpeta, Assam. Journal of Entomology and Zoology Studies, 3 (1): 193-198.

Prasad, P.S., 1987. Socio-economic aspects of aquaculture enterprise in Bihar. Fishing Chimes, 7(11):34-39. 